\title{
Strategi pengembangan \\ layanan perpustakaan perguruan tinggi berbasis \\ teknologi informasi
}

\begin{abstract}
Muslina
Abstract

University Library is an information center for education and research development by supporting facilities and learning activities that function. As a services center provided optimally and efficiently according to the users needs. The improvement and development of University Library services based on information technology is being realized communicatively with users, stimulating a conducive and comfortable atmosphere for librarians and users. Skilled and qualified librarians or have expertise in information technology, active in delivering various attractive information and reaching users.
\end{abstract}

Keywords: University Library services, information technology

\section{Pendahuluan}

Perpustakaan merupakan agen perubahan (agen of changes) atau agen pembangunan dan agen budaya. Maksudnya bahwa perpustakaan itu menjadi tempat rujukan dan sumber informasi. Perpustakaan harus berperan aktif dalam memberikan informasi kepada pemustaka sehingga dampak dari informasi yang update setiap waktu, dapat memberikan solusi terhadap apa yang menjadi permasalahan yang ada di tengah masyarakat. Disitulah perpustakaan harus memberikan peran yang sangat penting sebagai solusi dari apa yang menjadi permasalahan tersebut. Perpustakaan merupakan suatu sarana penunjang bagi kegiatan belajar yang berfungsi sebagai pusat informasi untuk pengembangan, pendidikan, penelitian. Perpustakaan dituntut 
untuk dapat menyediakan pelayanan yang maksimal secara tepat dan cepat sesuai masing-masing kebutuhan pemustaka.

Perpustakaan adalah sarana penunjang esensial untuk menciptakan masyarakat informasi yang berkualitas. Berdasarkan pengamatan di lapangan terlihat bahwa pemustaka akan semangat apabila dapat merasakan manfaat dari perpustakaan. Pemustaka menganggap keberadaan perpustakaan penting jika mereka merasa terbantu. Mereka merasa senang jika selalu dapat menemukan informasi yang dibutuhkannya. Pemustaka sebagai pemangku kepentingan (stake holder) utama bagi perpustakaan.

\section{Kajian Pustaka}

Memang benar bahwa setiap orang membutuhkan informasi sebagai bagian dari tuntutan kehidupannya, sebagai penunjang kegiatannya, dan sebagai pemenuhan kebutuhannya. Rasa ingin tahu seseorang timbul karena ia ingin selalu berusaha menambah pengetahuannya. Krech, Crutchfield, dan Ballachey dalam Suwarno lebih jauh menjelaskan bahwa karena adanya kebutuhan untuk memecahkan masalah-masalah sosial maka seseorang termotivasi untuk mencari pengetahuan bagaimana caranya dapat memecahkan masalah tersebut. Salah satu cara untuk itu adalah mencari tambahan pengetahuan melalui membaca berbagai media massa dan sumber-sumber informasi yang banyak disediakan oleh perpustakaan. Ritual komunikasi dimulai ketika individu memasuki ruangan perpustakaan, mengisi buku tamu, menggunakan fasilitas temu kembali, menerima layanan, hingga ia meninggalkan perpustakaan.

Dari pendapat di atas dapat dijelaskan pustakawan tidak hanya memberikan layanan begitu saja akan tetapi bagaimana cara pustakawan berkomunikasi secara personal dengan pemustaka sehingga dapat menimbulkan kesan-kesan yang dapat 
memotivasi pemustaka untuk berkunjung ke perpustakaan. Terutama perpustakaan Perguruan Tinggi, karena bagaimanapun juga komunikasi sangatlah penting dalam menunjang peningkatan kualitas perpustakaan secara maksimal agar dapat menyajikan informasi-informasi yang semakin update.

Untuk menunjang kebutuhan dalam memenuhi informasi di perpustakaan di butuhkan tenaga sumber daya manusia. Seperti halnya di perpustakaan dibutuhkan tenaga pustakawa dalam menunjang pemenuhan kebuhan informasi bagi pemustaka. Pustakawa adalah seorang yang melaksanakan kegiatan perpustakaan dengan jalan memberikan pelayanan ke pada masyarakat sesuai dengan tugas lembaga induknya berdasarkan ilmu pengetahuan, dokumentasi dan informasi yag dimiliki melalui pendidikan. Pustakawan adalah seorang yang berkarya secara profesioanl dibidang perpustakaan dan informasi. Keberadaan pustakawan di dalam program studi ilmu perpustakaan juga akan menujang proses akreaditasi. Oleh sebab itu pengembangan perpustakaan dan pustakawan sangat berpengaruh terhadap layanan yang diberikan di perpustakaan. Apabila pengembangan perpustakaan rendah dan tidak didukung oleh tenaga pustakawan yang profesional maka untuk mencapai layanan prima berbasis teknologi informasi pada tahap ini sangat sulit dicapai. Oleh sebab itu makalah itu terfokus untuk mengkaji strategi pengembangan layanan perpustakaan perguruan tinggi berbasis teknologi informasi.

\section{Pembahasan}

\section{A. Pengembangan Layanan Perpustakaan Perguruan Tinggi}

Bicara mengenai inovasi pengembangan dan pemberdayaan perpustakaan tidak lepas dari layanan (Customer Care, peduli 
konsumen/ Costumer Satisfiction, kepuasan pelanggan/ Service Excelent, layanan yang bagus). Strategis dalam upaya mencapai hal tersebut terkait dengan banyak hal, misalnya apakah kecukupan jumlah dan kualitas sumberdaya manusia yang ada, apakah cukup mendukung sarana dan fasilitas yang memadai, apakah kebijakan mendukung terciptanya situasi yang mendukung, apakah networking terjalin dengan baik ditingkat lokal, regional, nasional bahkan international, apakah multi stake holder atau pemangku kepentingan memiliki kepedulian terhadap keberadaan perpustakaan, apakah masyarakat cukup bisa merasakan manfaat keberadaan perpustakaan atau masyarakat dan perpustakaan merasa memiliki keterikatan. Apakah setiap program yang dijalankan saling memiliki kesinambungan. Telaah dan kajian ilmiah perlu dilakukan untuk mendapatkan role model sehingga setiap apa yang dilakukan menjadi tepat guna bagi masyarakat dan tentunya sustainable.

Namun pengembangan perpustakaan dalam konteks pembahasan ini adalah pengembangan perpustakaan demi menunjang atau meningkatkan kualitas layanan yang di berikan kepada pemustaka yang mengikuti perkembangan zaman, eg. Berbasis TI. Usaha atau inovasi perlu ditingkatkan dalam mengembangankan layanan di perpustakaan perguruan tinggi. Disamping itu usaha tersebut tidak bisa berjalan tanpa adanya dukungan dari pustakawan profesional yang terampil atau memiliki keahlian dalam bidang teknologi informasi (Information technology skill).

\section{B. Pustakawan}

Pustakawan adalah orang yang memberikan dan melaksanakan kegiatan perpustakaan dalam usaha pemberian layanan kepada masyarakat sesuai dengan misi yang diemban 
oleh badan induknya berdasarkan ilmu perpustakaan, dokumentasi, dan informasi yang diperolehnya melalui pendidikan.

Pustakawan juga merupakan seseorang yang telah diangkat oleh pejabat yang berwenang untuk menjabat atau melaksanakan tugas-tugas sehubungan dengan penyelenggaraan perpustakaan karena dianggap memenuhi syarat-syarat tertentu.

Pustakawan dikalangan masyarakat bukanlah sebuah profesi yang familiar seperti dokter, dan guru. Oleh sebab itu keberadaan pustakawan dianggap tidak penting, padahal pada hakikatnya pustakawan juga merupakan sebuah profesi yang mulia, pustakawan berasal dari masyarakat, namun ketidakpercayaan diri dari pustakawan yang membuat profesi sebagai pustakawan dianggap kurang penting dalam masyarakat. Maka dari itu pustakawan harus memiliki rasa percaya yang tinggi dalam menjalankan profesi seorang pustakawan.

Pustakawan adalah seseorang yang berkerja di perpustakaan untuk melayani masyarakat yang membutuhkan informasi. Oleh karena itu profesi pustakawan sangatlah penting dalam mendukung terpenuhinya informasi-informasi bagi pemustaka luas. Salah satu bukti peran pustakawan adalah menyebarkan informasi keseluruh pelosok negeri. Sehingga kita tidak perlu kurang percaya diri dengan menjadi seorang pustakawan. Karena profesi pustakawan sama juga dengan profesi lainnya, seperti profesi dokter, dan guru yang sama-sama melayani masyarakat( pemustaka), namun cara memberikan pelayanan yang berbeda-beda namun pada dasarnya tetap mempunyai tujuan yang satu yaitu melayani pemustaka.

Maka dari itu, keberadaan pustakawan yang penuh percaya diri di dalam masyarakat akan mengubah cara pandang 
masyarakat terhadap profesi pustakawan. Karena perlu kita sadari bahwa sebuah profesi akan memiliki nilai positif apabila kita memiliki keahlian dalam bidang yang kita jalani untuk terus memberikan pelayanan dan menciptakan rasa percaya diri menjadi seorang pustakawan dalam lingkungan pemustaka di Perpustakaan Perguruan Tinggi

Pustakawan merupakan komponen yang sangat penting dalam mencapai keberhasilan layanan perpustakaan, oleh karena itu staf perpustakaan (pustakawan) harus memadai dari segi jumlah dan mutu untuk memenuhi kebutuhan pelayanan dan program yang dikembangkan di perpustakaan perguruan tinggi. Pustakawan perpustakaan perguruan tinggi idealnya lulusan perguruan tinggi (S1) Ilmu Perpustakaan. Disamping itu, ada kalanya perpustakaan perguruan tinggi merekrut sarjana berbagai bidang ilmu sebagai pakar subjek untuk ditempatkan pada bidang layanan rujukan, pengolahan, teknologi informasi, atau bidang lain, atau mahasiswa yang bekerja paruh waktu di perpustakaan untuk melakukan tugas- tugas seperti misalnya penjajaran koleksi di rak (shelving).

Beberapa keterampilan yang harus dimiliki seseorang yang berprofesi sebagai pustakawan sebagai berikut :

1. Pustakawan hendaknya cepat berubah menyesuaikan keadaan yang menantang,

2. Pustakawan adalah mitra intelektual yang memberikan jasanya kepada pemakai. Jadi seorang pustakawan harus ahli dalam berkomunikasi baik lisan maupun tulisan dengan pemakai,

3. Seorang pustakawan harus selalu berpikir positif,

4. Pustakawan tidak hanya ahli dalam mengkatalog, mengindeks, mengklasifikasi koleksi, akan tetapi harus 
mempunyai nilai tambah, karena informasi terus berkembang,

5. Pustakawan sudah waktunya untuk berpikir kewirausahaan. Bagaimana mengemas informasi agar laku dijual tapi layak pakai,

6. Ledakan informasi yang pesat membuat pustakawan tidak lagi bekerja hanya antar sesama pustakawan, akan tetapi dituntut untuk bekerjasama dengan bidang profesi lain dengan tim kerja yang solid dalam mengelola informasi.

Selain memiliki kegiatan serta tugas yang harus dilaksanakan diatas, seorang pustakawan juga mempunyai peranan dalam perpustakaan sebagai berikut:

a) Edukator

Sebagai edukator (pendidik), pustakawan dalam melaksanakan tugasnya harus berfungsi dan berjiwa sebagai pendidik. Sebagai pendidik, ia harus melaksanakan fungsi pendidikan yaitu mendidik, mengajar dan melatih. Mendidik adalah mengembangkan kepribadian, mengajar adalah mengembangkan kemampuan berfikir, dan melatih adalah membina dan mengembangkan keterampilan.

b) Manajer

Pada hakikatnya pustakawan adalah "manajer informasi" yang mengelola informasi pada satu sisi, dengan pengguna informasi pada sisi lain. Informasi yang banyak dan terdapat dalam berbagai wadah yang jumlah selalu bertambah harus dikelola dengan baik. Kebutuhan informasi pengguna merupakan dasar dasar pengelolaan informasi.

c) Administrator

Sebagai administrator pustakawan harus menyusun, melaksanakan, dan mengevaluasi program perpustakaan, 
serta dapat melakukan analisis atas hasil telah dicapai, kemudian melakukan upaya-upaya perbaikan untuk mencapai hasil yang lebih baik.

d) Supervisor

Sebagai supervisor pustakawan harus: (1) Dapat melaksanakan pembinaan profesional, untuk mengembangkan jiwa kesatuan dan persatuan antar sesama pustakawan, sehingga dapat menumbuhkan dan peningkatan semangat kerja, dan kebersamaan; (2) Dapat meningkatkan prestasi, pengetahuan dan keterampilan, baik rekan sejawat maupun masyarakat pengguna yang dilayaninya; (3) Mempunyai wawasan yang luas, pandangan jauh ke depan, memahami beban kerja, hambatanhambatan, serta bersikap sabar, tetapi tega, adil, objektif dalam melaksanakan tugasnya; (4) Mampu berkoordinasi, baik dengan sesama pustakawan maupun dengan para pembinanya dalam menyelesaikan berbagaipersoalan dan kendala, sehingga mampu meningkatakan kinerja unit organisasinya.

Berdasarkan pendapat di atas dapat diketahui bahwa pustakawan memiliki banyak peran, yaitu sebagai sumber edukator, manager, pustakawan juga berperan sebagai pengayak sumber informasi, sebagai teknisi dan sebagai konsultan informasi untuk mengembangkan perpustakaan sesuai dengan perkembangan ilmu pengetahuan dan teknologi dalam memenuhi kebutuhan informasi bagi pengguna perpustakaan.

Sementara itu, yang dimaksudkan dengan pengelolaan perpustakaan adalah kegiatan mengurus sesuatu, dapat diartikan sebagai mengurus atau menyelenggarakan perpustakaan. Dengan demikian peran pustakawan tidaklah ringan seperti pendapat 
pada umumnya yang mengatakan bahwa seorang pustakawan merupakan pegawai tak bermutu yang kerjanya menunggui tumpukan buku-buku.

Pustakawan dituntut untuk aktif dan giat bekerja dalam menyampaikan informasi dalam aneka produk kemasan-kemasan yang menarik dan sampai kepada pemustaka. Pelayanan pemustaka yang diberikan oleh suatu perpustakaan pada umumnya meliputi pelayanan administrasi, pengadaan koleksi, dan pendayagunaan koleksi.

Kualitas pelayanan menjadi ukuran manfaat tidaknya suatu perpustakaan bagi pemustakanya. Definisi mengenai kualitas suatu pelayanan memang tidak dapat diterima secara universal. Menurut Kotler, pelayanan (jasa) didefinisikan sebagai setiap tindakan atau perbuatan yang dapat ditawarkan oleh suatu pihak lain yang pada dasarnya bersifat intangible (tidak berwujud fisik) dan tidak menghasilkan kepemilikan sesuatu. Sebagaimana telah dijelaskan di atas, layanan perpustakaan tidak berorientasi kepada hasil fisik, meskipun demikian pustakawan tetap diminta untuk kreatif dalam menyajikan kemasan informasi yang diberikan kepada pemakai.

\section{Penutup}

Strategi layanan perpustakaan perguruan tinggi berbasis teknologi informasi sudah selayaknya berorientasi pada kebutuhan pemustaka, sehingga kepuasan pemustaka selalu diutamakan dalam rangka meningkatkan hubungan antara pemustaka dan pustakawannya. Setiap pelayanan terdapat berbagai faktor yang mempengaruhi. Faktor-faktor tersebut bisa berasal dari dalam maupun dari luar sistem penyelenggaraan. Faktor yang mempengaruhi tesebut di antaranya: 
1. Faktor kesadaran para pejabat serta petugas yang berkecimpung dalam pelayanan,

2. Aturan kerja yang melandasi kerja pelayanan,

3. Pendapatan yang dapat memenuhi kebutuhan hidup minimal,

4. Faktor ketrampilan petugas,

5. Faktor sarana dalam pelaksanaan tugas pelayanan,

6. Faktor organisasi yang merupakan alat serta sistem yang memungkinkan berjalannya mekanisme kegiatan pelayanan. Berdasarkan pendapat di atas, maka dapat dipahami bahwa mendengarkan "suara pemustaka" merupakan suatu hal yang perlu dilakukan terutama perpustakaan perguruan tinggi. Jadi meningkatkan kualitas layanan suatu perpustakaan harus dimulai dari diri sendiri sebagai pustakawan sejati dalam penyampai informasi. Informasi yang di sajikan juga selalu selaras dengan kebutuhan pemustaka, dalam hal ini mahasiswa, dosen dan staf yang menjadi pemustaka perpustakaan perguruan tinggi. Agar layanan perpustakaan perguruan tinggi berbasis teknologi dapat terwujut nyata, pastilah di kelola oleh pustakawan profesional yang selalu meningkatakan ketrampilan dan kualitas pribadi dalam memberikan kepuasan pemustaka. Kewajiban pustakawan terhadap diri sendiri sebagaimana tercantum dalam kode etik pustakawan. Diantaranya, setiap pustakawan dituntut untuk selalu mengikuti perkembangan ilmu, memelihara akhlak dan kesehatan untuk dapat hidup dengan tenteram, dan bekerja dengan baik; serta selalu meningkatkan pengetahuan dan ketrampilan dalam pergaulan dan bermasyarakat.

Dapat disimpulkan bahwa segala kemajuan teknologi informasi tidak akan benar benar bermakna dan berkualitas tanpa 
ketulusan dan profesionalisme pustakawan dalam melayani pemustakanya

\section{Daftar Pustaka}

Achmad, dkk. (2012). Layanan Cinta Perwujudan Layanan Prima. Perpustakaan. Jakarta: Sagung Seto.

Darmono. (2001). Manajemen dan Tata Kerja Perpustakaan Sekolah. Jakarta : Gramedia Widiasarana Indonesia.

Hermawan, Rachman dan Zen, Zulfikar. (2006). Etika Kepustakawanan: Suatu Pendekatan Terhadap Kode Etik Pustakawan Indonesia. Jakarta: Sagung Seto.

Laksmi. (2006). Tinjauan Kultural Terhadap Kepustakawanan: inspirasi dari sebuah karya Umberto Eco. Depok: Fakultas Ilmu Budaya.

Sulistyo-Basuki. (1993). Pengantar Ilmu Perpustakaan, Jakarta: Gramedia Pustaka Utama, 1993.

Sutarno NS. (2006). Manajemen Perpustakaan, Jakarta, Sagung Seto.

Triniharyanti. (2017). Inovasi Pengembangan Dan Pemberdayaan Perpustakaan Masyarakat, Dalam www.triniharyanti.id/2010/04/inovasi-pengembangandan-pemberdayaan.html. Diakses pada tanggal 7 Juli 2017.

Yusup, Pawit M. (2009). Imu Informasi Komunikasi, dan Kepustakaan. Bandung: Bumi Aksara. 